Marquette University

e-Publications@Marquette

$5-1-1990$

\title{
The Bigman Metaphor for Entrepreneurship: A "Library Tale" with Morals on Alternatives for Further Research
}

Alex Stewart

Marquette University, alex.stewart@marquette.edu

Published version. Organization Science, Vol. 1, No. 2 (May 1990): 143-159. DOI. C 1990

INFORMS (Institute for Operations Research and Management Sciences). Used with permission. Alex Stewart was affiliated with Brock University at the time of publication. 


\title{
THE BIGMAN METAPHOR FOR ENTREPRENEURSHIP: A "LIBRARY TALE” WITH MORALS ON ALTERNATIVES FOR FURTHER RESEARCH*
}

\author{
ALEX STEWART \\ Brock University, Department of Management and Marketing, \\ School of Administrative Studies, St. Catharines, Ontario, Canada L2S 3A1
}

\begin{abstract}
Melanesian Bigmanship (a meritocratic, enacted career of political-economic leadership) is recounted as an anthropological metaphor for entrepreneurship. This "library tale" has two purposes. The first is a demonstration of conceptual uses of ethnographies for developing grounded theory. Propositions are generated on entrepreneurial orientations and opportunity structures. Opportunities are seen to arise in the creation of linkages between spheres of exchange, or fields in which an object exchanges at different values. Entrepreneurial tactics, such as converting between spheres, call for skills in informal planning, astute use of timing, and networking. These "tactical" skills coexist with "moral" skills, in persuasiveness, the manipulation of norms, and recognition of culturally specific opportunities. The entrepreneur's acts thus create a dialectic of moral (normatively approved) and tactical (instrumentally enacted) changes.

The second purpose is a demonstration of methodological implications of ethnographies. Library tales are helpful in the process of "constant comparison" (Glaser and Strauss 1967), by augmenting available, within-site observations with other sources of insight, and of potential disconfirmation of emerging ideas. However, there are limits to the "translation" of library tales. There thus arises a need for observations tailored to specific comparative questions. Multiple site case replication research is suggested for tailoring observations to synchronic, comparative uses. Processual, continuous contextual analysis is suggested for diachronic, intensive followups to such questions as the relationships amongst constraints and individual agency.
\end{abstract}

(ENTREPRENEURSHIP; ETHNOGRAPHY; EMBEDDEDNESS; LEADERSHIP)

If anthropology is the "forgotten" discipline in management thought (Morey and Luthans 1987), certain of its subfields have never been remembered. Its studies on entrepreneurship have suffered regrettable neglect. These studies are holistic, and empirical in the manner of all observational research (Whyte 1987). Further, they help us to generate theory - a seminal area for entrepreneurial studies. Therefore, this paper interprets these studies for organizational researchers.

This introduction should not be entirely abstract; theory in anthropology is grounded in specifics. Nor ought it to plunge the reader cold, straight into generating theory; the object for our reflections is, for most, obscure. Illustrations are needed, but these cannot be narrated as if interpretations, and implications, were self-evident. Therefore, this paper aims not only to introduce concepts, but also to suggest methods by which anthropological, and other case studies, can be used for advancing the field of organizational research.

\section{The "Bigman" Metaphor}

\section{Political-Economic Leadership}

We start with a cruise to the Southwest Pacific, to tour an extended example: the Melanesian "Bigman". In much of Melanesia, "Bigman" was the pidgin word for a

*Accepted by Arie Y. Lewin; received February 1988. This paper has been with the author $2 \frac{1}{2}$ months for 2 revisions. 
personal career path of leadership (Lindstrom 1981). This leadership was economic and political. In his most notable activity, the direction of rivalrous feasts (see "Rivalry", below), the Bigman represented a political community, and engaged in trade. Bigmen also became leaders in the development of modern businesses (Finney 1973; Strathern 1972, 1987; cf. Brown 1987). The continuity from Bigman to "businessman" prepares us for the notion that their worlds were at least as entrepreneurial as our own.

Bigman systems were entrepreneurial in terms of culture, and rewards for achievement. Competition for Bigman standing was required for the fully human, adult life (Burridge 1970, pp. 109, 140, 228; 1975; Meggitt 1974, n. 34; Oliver 1949a; Panoff 1985; Pflanz-Cook and Cook 1982; Strathern 1972). ${ }^{1}$ Children were therefore raised to emulate this rivalry. Meggitt found that "men encourage their sons to take an active interest in all kinds of exchanges and frequently give them minor valuables, to see whether the lads can convert these through shrewd dealing into objects of greater worth" (1974, pp. 75-76). They learned respect for the Bigman, disdain for his opposite: the "Rubbish Man".

A small minority of the adult male population, Rubbish Men were the underclass amongst the larger minority that did not become Bigman contenders. They were the orphans, the mentally weak, the nonconformists, the descendants of extinct kindreds, and above all, the refugees. Having lost their positions in adult social networks, they were viewed as "walking corpses" (Panoff 1985, p. 66; see also Burridge 1970, pp. 85, 112; 1975; Lepervanche 1968; Meggitt 1974; Strathern 1971, pp. 51-52, 143, 169, 187-189). They seemed to be devoid of valued qualities: they were incompetent economically (although not always poorer than the typical Melanesian: Panoff 1985).

Rubbish Men were moral foils in societies that valued openness to achievement. A successful Bigman had had to achieve: his status could not be conferred by other means; it was not even an "office". It was not a position abstracted from the enactment and redefinition of expectations. It was a quality of leadership within a meritocracy (Strathern 1971, p. 221), although a seriously flawed meritocracy, as women were largely excluded (cf. Tiffany 1987).

\section{The Bigman's Career}

Startups into the Bigman career called for attention to personal ties. The would-be Bigman needed access to "a large amount of capital, but it [did not] necessarily have to be his own capital" (Oliver 1949a, p. 17). He would be given a pig by a "close relative" (p. 8), so certain kinship ties could give a head start. However, any gift carried obligations, and most young males could be mentored by a Bigman (Strathern 1971, p. 199).

Startups called for what we term "sweat capital". Ambitious youths would work very hard, often as "an industrious gardener" (Burridge 1970, p. 75). Sahlins found a "tenfold variation in output per household", between those trying to create Bigmen and those not (1972, p. 115). Work in the gardens created goods for the feasts, but work in other activities could be converted to capitalizing the career. Some Bigmen were craftsmen, some traders, some magicians (Salisbury 1966; cf. Burridge 1975).

Enterprising men might also convert from a less peaceful role. There were, Keesing argued, three main leadership roles; the priest, the Bigman, and the "warleader/bounty-hunter" (1985, p. 237). The "retired killer might become saintly priest" (p. 247); he might convert his bounty spoils into goods for Bigman exchanges. The

\footnotetext{
${ }^{1}$ Presumably other leadership roles (priest, war leader) were also goals, but Burridge argued that competence in food production was the most highly valued moral strength, and the Big Man role thus the most valued (1975).
} 
roles were "separated" and distinct; conversion was necessary (Strathern 1971, p. 225; and Burridge 1975). Bounties were exchanged for ritual objects, and these were entered into the Bigman channels of reciprocity.

\section{Creating a Network: Mobilizing by Indebting}

Since feasting was labor intensive, support from both followers and wives would be needed. A pig pen had to be built, a club house, a platform for displaying gifts of food. "Puddings" had to be baked, musicians hired, opossums slain. These jobs were done with a quite hierarchical division of labor, provided they were directed by a Bigman (Burridge 1975; Oliver 1949a, b).

Bigmen needed the help of an industrious family. Here, success bred success, since the sorts of exchanges that won the Bigmen prestige could also be used to accumulate wives. (Bigmen aspired to 8 or 10 marriages; some had 15 to 20.) Thus, to increase their access to household labor, they sought to entice outsiders to their followings. For example, Bigmen recruited Rubbish Men into their villages to swell the ranks of supporters, and then "thoroughly exploited" their underlings (Meggitt 1974, p. 75). Recruitment, however, needed sweat capital: hard work put others in one's debt; work on one's behalf would once again be repaid, by a banquet.

In mobilizing local work, the Bigman had to avoid two contrary dangers. One was subsidizing "parasites" as supporters (Burridge 1970, p. 79). The other was extracting too much and driving supporters off, to follow rivals. This danger constrained him to be a "moral" leader, who would not induce envy or shame and stand accused of sorcery. Rubbish Men especially were thought to be "jealous", and liable to poison a Bigman for a bribe (Burridge 1970; 1975).

The defense against accusations, as against sorcery itself, was generosity. Similarly, the mere possession of pigs brought little prestige for the miserly. Goods had value only if deployed, in the framework of community norms (Burridge 1970, p. 31). A Bigman adhered to these norms, inasmuch as generosity was part of his role. He tried to "secure dependents, who become indebted to him, by giving generously on every possible occasion" (de Lepervanche 1968, p. 177). In his initial exchanges outside his own domestic unit, as he built a track record of feasting and accumulating pigs, the terms of trade went against him. He paid more than "market" price.

The size and quality of a Bigman's exchange network were measures of his status (Burridge 1975). The network was also indirectly a resource. Alliances with other Bigmen would be needed to assemble the labor for a feast. Feasts required the marshalling of "more valuables at a single time than [one] would be able to accumulate in a decade" (Keesing 1976, p. 374). Further, while there was a market in pigs, nurturing ties with suppliers required many efforts in networking (Oliver 1949a; Strathern 1971).

Energies were invested in aligning a wide-ranging set of exchange partners. As in all networking, indirect social relationships would be indirectly managed. A simple example illustrates the point that networks are not merely dyadic or direct. The Bigman might

\footnotetext{
make this kind of proposal to a friend: 'Your young daughter will soon be of marriageable age. When her wedding is celebrated I will contribute a 60 -span pig to the feast. But in the meantime, you can repay my "gift" by trading that 60 -span sow of yours for that [larger] tusker of your father-in-law's and by giving me the tusker for my feast. After all, he's your father-in-law and will not be a hard bargainer with you, whereas he and I are mere acquaintances' (Oliver 1949b, p. 21). (For more complex deals, see pp. 22-23; 1949b, p. 17; Strathern 1971, p. 221.)
}

Some Melanesian societies had formalized networks of complex credit systems, known by such terms as moka and te. These "chains" of delayed exchange and financial 
arrangements were managed by the Bigmen (Strathern 1971, p. 4). Strathern saw in these chains "the tendency towards inflation and increase in the size of the networks, velocity of circulation, and volume of exchange" (1983, pp. 80-81). His explanation was suggestive of quick-flip promoters: the chains freed the Bigmen from the need to keep and care for pigs, but this freedom from operating duties did not leave the Bigmen free to make any deal they pleased. On the contrary, the chains helped to construct the normative systems within which Bigmen worked. As in all informal credit systems, they imposed a sturdy social control, if only through the multiple pressure points by which sanctions can be imposed in any complex network (cf. Cohen 1969; and Benedict 1968; Light 1972).

\section{Rivalry}

Crucial decisions did underlie the "status-climbing feasts" (Strathern 1971). These multi-functional activities were (with regional variations) started and administered by Bigmen, who had to choose whom to indebt. They could gain a notch of Bigman reputation, by overwhelming a rival with more gifts than he could repay in one or two years. Oliver noted that "an ambitious mumi [Bigman] who is also shrewd will carefully estimate his victim's ability to repay, and will go just beyond that limit... Sometimes two closely matched rivals will compete for years,... until one of them bankrupts himself and all of his relatives" (1949b, p. 14). The shrewd feast-giver could kill two birds with one stone, by inviting first a rival who would be humiliated by having to decline.

Triumph over an insolvent rival would be bittersweet. It would be better to make a show of the other's inferiority, but still be repaid. Guests wanted more gifts, in order to repay their own creditors. Thus, the risk in feasting lay not only in the chance of defaulting but also in the chance of being defaulted against. This risk, which was greatest with weakly connected debtors, derived from the norm that recipients not hoard their gifts, and from the perishability of gifts of food (Burridge 1975).

Weaker players, whose claims could be postponed, had little choice but to continue making small advances in the hope of an eventual repayment. Stronger players, frustrated by the difficulties of achieving victory, were driven to overextension. The very cause of potential default, the recipients' reinvestment of gifts at the same time made it hard to defeat them; the complexity of credit chains made victory elusive. Bigmen therefore were tempted to overcommit themselves in the competition for supporters, but this was played upon by rivals who tried to take advantage of divisions. Divisions were further aggravated by succession problems, in which older men refused to step aside for younger aspirants.

\section{The Spoils}

Once an aspirant had become a Bigman, what was the prize in his triumph? It was, in part, and perhaps most importantly, "prestige", a "name", and "status". Meggitt argued that the Bigmen he studied "compete for prestige [not] just for its own sake" but for the sake of their highest moral value, the maintenance of territory, as prestige enabled a leader to attract "military allies and wives" (1974, pp. 63, 90-93).

The gain was, however, more than prestige; it incorporated a version of "profit". Bigmen had an acute accounting sensibility and knew their net obligations. ${ }^{2}$ They took "pains to avoid those situations where generosity may be asked of them and yet count for little" (Burridge 1970, p. 78). They broadcasted their own generosity and their rivals' humiliations. They managed to use other people's "money" to advance their

\footnotetext{
${ }^{2}$ The Big Man was a "genius at financial manipulation” (Keesing 1976, p. 374; Burridge 1970, p. 44; cf. Keesing 1978, p. 50, and Sahlins 1972, p. 249).
} 
own causes: "The host, and not his financial backers, receives acclaim... U'ta of Mi'kahna was a notorious promoter. Once he gave a feast and distributed an equivalent of 1,500 spans of money, 130 of which he himself contributed. He gained the prestige and his relatives paid the bill" (Oliver 1949b, pp. 14, 18). Finally, they "profited" once they were recognized as Bigmen, since the terms of trade then switched in their favor. No longer need they pay more than "market" rates; they now received more than they gave. ${ }^{3}$

The rewards included profit; they also included power. Bigmen took advantage of the weak, paying off those whose support had to be kept, but ignoring their debts to the feeble. The latter could be physically threatened by the "Bigman's proteges" (Meggitt 1974, p. 82). Even in this relatively meritocratic system a drift towards the monopolization of entrepreneurship occurred. "One can distinguish an enduring inner network of Bigmen... attempt[ing] to achieve monopolistic and profitable control of transactions" (Meggitt 1974, p. 82). A Bigman considered his manipulations to be "both a diacritical mark [signifying inclusion in the circle] and a privilege of Bigmen as a category" (Meggitt, as above).

Power was one reward; cultural sanction of that power was another. The Bigman did gain materially. "But", Oliver added,

his intangible rewards are even greater. He can sit in his club house and listen to the flattery of his followers, he can call upon supernatural aid whenever he needs it, and he can rest assured of a comfortable place in the afterworld (1949b, p. 35).

\section{Bigmanship as Entrepreneurship}

\section{Library Tales}

This account of Bigmanship has been styled as a "realist tale" (a matter-of-fact reconstruction that may or may not be evocative, but certainly sounds definitive) (Van Maanen 1988). Its research implications will be clearer, however, if we term it a "library tale", a term that will not be found in Van Maanen's (1988) typology of ethnographic forms. There can be no surprise that he overlooked the genre. Its fall from grace succeeded its long-lost, unjustified preeminence; no one now would seek to be cast as an "armchair anthropologist" (Barrett 1984; I. M. Lewis 1976). On one hand, this fall into stigma is not to be lamented; library tales are idle speculations, that deserve to be directed to their proper job of helping us to make sense of data. On the other hand, their value in this job is such that even the most muddy-booted, dogged of field researchers is also an armchair anthropologist.

This paradox derives from a process by which field researchers generate understanding. Glaser and Strauss (1967) discussed it as "constant comparison", but it remains largely undocumented: a hard-to-reconstruct dialectic between specific, ambiguous (emic and barely translatable) data, and any observations that promise points of contrast for hunches, propositions, and, it is hoped, grounded theory. Manifold

\footnotetext{
${ }^{3}$ Salisbury calculated a "50 percent return on investments" in exchange networks, and a " 20 percent return... in materially productive goods" (1966, p. 124; and pp. 121-122; cf. Strathern 1971, pp. 1-2, but see pp. 93-94; Lindstrom 1984; Oliver 1949a, b; Sahlins 1972, pp. 248-251). Big Men "pushed" their creditors: a Big Man "is especially likely to be offered 'bargains' either because the seller expects future favors or because he feels grateful for past financial or legal aid" (Pospisil 1968, p. 384). Weaker parties feared being asked to repay loans. Other advantages for Big Men lay in the manipulation of marriage payments (de Lepervanche 1968) and undistributed associational returns (Salisbury 1966).
} 
observations within a single site do offer chances for disconfirmations (Becker 1958; Campbell 1975; Glaser and Strauss 1967), but these rarely will suffice. Observations for quite specific contrasts will thus be retrieved with a wide-ranging scan of the library.

This scan may create another paradox of grounded theory. On one hand, studies center on the particularities of rich descriptions, and seem incommensurably contextbound. On the other hand, comparisons are made freely, even loosely, with myriad cross-cultural instances. This follows from the creative comparison of case material, deeply understood, with a wide array of literatures (Glaser and Strausss 1967; Kanter 1977, Appendix I; Stewart 1987; Yin 1984).

\section{Developing a Bigmanship Concept by Constant Comparison}

Literatures are used intensively but selectively, due to a search for understanding that centers on site-specific data. Examples are Crozier's (1964) work on French bureaucracy, Kanter's (1977) on androcentric management, and (with a risk of a hint of "confessional tales") my own (1989) on team entrepreneurship. I was for some time uncertain I did mean "entrepreneurship", a term that seemed less a concept than a prize in a definitional free-for-all. Anthropologists, moreover, had proved no more able than others to reach a consensus. Rather, Hart argued, "it is clear that the word is normally used by analysts to mean whatever they like" $(1975$, p. 6).

This problem led Brockhaus (1987) to urge that authors who use the word specify clearly their own intended referents. My referent, in further pursuing the Bigman metaphor, will be propositions based on echoes between the Melanesian Bigman and other, cross-cultural records. The object is tentative theory grounded in a tale. The rationale for this is that the tale illuminates non-Melanesian materials, which, in turn, shed light on the islanders' case. This potential of the Bigman metaphor for thinking about entrepreneurship has been commonplace in anthropology, in which the Bigman has been called "the very epitome of the entrepreneur" (I. M. Lewis 1976, p. 232). Moreover, a study of cross-cultural uses of the metaphor (van Bakel, Hagesteijn, and Schroeder 1986, p. 211) concluded that "we have come to consider 'Big-Man' as one manifestation of leadership in ... any empirical society, occurring simultaneously with other types of power." (See also Lindstrom 1981.) Related conclusions are that "entrepreneur" and "Bigman" should be seen not as definable things, but as aspects of a shifting, varied set of social roles (Barth 1963; van Bakel et al. 1986). ${ }^{4}$ These are among the reasons that definitions have proved elusive.

Definitional dissensus also reflects entrepreneurial activities, the opportunistic and boundary-defying nature of which is reflected in anthropological definitions (Barth 1963; Belshaw 1965, p. 116; Glade 1967). Emphasis on such attributes, familiar from Bigmanship, suggests that cross-cultural studies might be translatable into Melanesian terms, just as the reverse appears likely. Thus, we can launch a tour of cross-cultural notions, not with a definition in the usual sense, but with an expected confluence: Entrepreneurship is the recognition and pursuit of opportunities for the expansion of goods, without regard for the current control of resources.

\section{Gaps, Conversions, and Bridges}

What, then, can be said about entrepreneurial opportunity? In anthropology, an influential answer was given by Barth: it is a chance to bridge, and to create

\footnotetext{
${ }^{4}$ Bigmanship varied over time (Pflanz-Cook and Cook 1982) and space, and Lindstrom (1981) has cautioned against generalization. Nonetheless, area specialists have generalized to an ideal typical Bigmanship (Burridge 1970, 1975; Keesing 1976; Sahlins 1963, 1972; Strathern 1972). I use the term Bigman rather than Big Man for two reasons: possible androcentric bias in fieldwork (Tiffany 1987), and the speculative, ideal-typical nature of the referent.
} 
conversions between, spheres of exchange. This fits the Melanesian example, in which a career could be capitalized by the returns from work in pottery, magic, trade, bounty hunting, etc. These returns, however, could not circulate directly in the institutionally separate "sphere" of Bigman exchanges. They had first to be traded for ritual objects, and thereby "converted" to values in the Bigman's sphere. Barth saw in such conversions a universal entrepreneurial tactic.

Barth identified two spheres of exchange (amongst an African people): a cash sphere, and another that centered on labor-for-beer (1967, pp. 149, 156). A "sphere" is a set of acceptable exchanges amongst categories of values. That is, it specifies not only what one can "buy" with particular goods, but also what one cannot. For example, labor for cash or beer for cash were unacceptable exchanges in the labor for beer sphere. For such proscriptions to stick there must be, between the spheres, recognizable barriers (Barth 1963, 1967). Respect for the barriers will, Barth argued, "allow considerable discrepancies of evaluation to persist as between items located in different spheres" (1967, p. 167). "Entrepreneurs will", therefore, "direct their activity pre-eminently towards those points in an economic system where the discrepancies of evaluation are the greatest, and will attempt to construct bridging transactions" (Barth 1967, p. 171). (For Melanesia, see Meggitt 1974, p. 87, and Sahlins 1972, pp. 209, 252; for general references, I. M. Lewis 1976, pp. 216-220; Moench 1971; and Robben 1984.)

\section{How Is the Opportunity Seen?}

Bridging roles are based on the recognition of discrepancies of evaluation, which requires an edge in information about both "sides" of the "bridge" (Burridge 1970; Glade 1967; Lindstrom 1984; Long 1975; Moench 1971; Salovesh 1978). Because this requires an information network, bridgers will commit time, energy, travel, and sociability to develop their personal networks (Long 1975). For many entrepreneurs their "most significant resource" is a ramifying personal network (Schneider and Schneider 1976, p. 11). Networks as assets offer the benefits of flexibility, low "overhead", and low initial costs (p. 104). These benefits suggest that networks can be assessed according to traits. A more general assessment can be based on Granovetter's (1973) distinction between "strong" and "weak" ties.

In order to gain access to strategic information, the entrepreneur needs an extensive set of weak ties; in order to mobilize, the entrepreneur needs strategic strong ties; that is, multidimensional ties with moral investments. Entrepreneurs can thus be expected to have particularly extensive weak ties, and strategic strong ties. (Schneider and Schneider 1976 showed this for entrepreneurs of their Sicilian study.) Extensive weak ties are needed for manipulating indirect ties, for solving the problems of long distance trust, and converting across spheres. Strong ties also are needed, for capitalization by sweat capital, and for further network investments to be made at lower costs (Long 1979). Strong ties with well-connected people are needed to set in motion particular indirect effects (Cohen 1969; Long 1975, 1979; Schneider and Schneider 1976). Strong ties are needed for networking itself, because networking (as distinct from socializing) is the manipulation of the effect on oneself of indirect ties (Bott 1971; Gulliver 1971).

For Bigmen, network decisions were strategic decisions, and much of their skill was rooted in network intelligence. They had to choose "to exchange under one rubric rather than another, to give to this group, but not to that, or to concentrate their gifts [investments] mainly in one direction" (Strathern 1971, p. 131). They made decisions on which partnerships to sustain, to add, or to drop. They learned to know " the interrelationships of others,... [and to be able to] lend support when it seems advantageous, remain aloof if necessary" (Burridge 1970, p. 53). 


\section{How Is the Opportunity Seized?}

\section{The Moral Embeddedness of Entrepreneurship}

Implicit in the work of anthropologists is the view that entrepreneurship is a social and a cultural process (Greenfield and Strickon 1986), that it is "embedded" in the total web of social life. Embeddedness is a concept first proposed by Polanyi (1957), according to whom, "Man's economy, as a rule, is submerged in his social relationships. He does not act so as to safeguard his individual interest in the possession of material goods; he acts to safeguard his social standing, his social claims, his social deserts" (1957, p. 46; cf. Granovetter 1985). "As a rule", then, there is embedding. But there are occasions, such as capitalist revolutions, in which there are movements towards disembedding. Opportunities arise that can only be exploited by violating traditional claims. In Polanyi's example, the technology of industrialism called forth the revolutionary creation of markets in labor and land.

\section{The "Moral" and the "Tactical"}

Western industrial history led to an association between laissez-faire liberalism and entrepreneurial classes (Polanyi 1957). It also led to an association, in early anthropological works, between entrepreneurship and disembedding. Scholars such as Barth reacted against a social science tradition that seemed to underestimate individuals, by depicting them as conforming to, and even constituted by, the normative constraints of society (e.g., Durkheim 1974). The human actor of this tradition was in a morally defined social order. The entrepreneur represented, by contrast, the goal-directed, opportunistic actor who manipulates normative patterns, who innovates, who uses components of culture, for instrumental ends (Barth 1963; Keesing 1976, pp. 363-364; Reed 1988). This actor is at, as well as in, a society.

The individual's tactics, and normative orders within which all tactics gain meaning, are fundamental dimensions of human activity. They can be called the "tactical" and "moral" dimensions. (This usage borrows from Bloch 1971. In everyday language, "moral" applies to special, "ethical" issues. In anthropology, the word means "normatively moral" (Burridge 1975, p. 87). It refers to a perspective on any activity, which is moral to the extent that it is "right" within the framework of the culture involved (Douglas 1983; Geertz 1984).)

This duality - the moral and the tactical-is a leitmotif of anthropological writing on entrepreneurship. It is so because the activities studied are so often associated with moral frameworks, or idioms, such as ethnicity, kinship, and even class and gender. These frameworks are bases for opportunity recognition, and for mobilization. None can be fully reduced to either the moral or the tactical dimension. Ethnicity, for example, is an idiom about morality (including the morality of resource competition), reinforced by emotionally charged images (such as "homeland"). Ethnicity is also a political-economic arena, proffering access to material and social resources (Kilby 1971; Light 1972; Parker 1988; Waldinger 1986). Thus, Cohen referred to groups mobilized in the language of ethnicity, religion and kinship as "informal interest groups" (1974, pp. 90-102).

Informal interest groups are not purely instrumental; they are moral at least to the extent that inclusion within their boundaries is an imprimatur that one plays the "right" game. Such marks often matter in business. All business, and especially venturesome business, has need of a basis in trust, and hence of social control (Cohen 1969; Levine 1985; Parker 1988). Informal social control of entrepreneurial activity through personal relationships reflects the embeddedness of "economic" acts in other spheres of life (e.g., "friendship", "religion"; cf. Van Velsen 1967). This is 
apparent not only from the Bigman tale but also from studies of Western businesses (Granovetter 1985; Light 1972; Reynolds and Miller 1988, p. 55).

Informal interest groups, and all social resources, are mobilized by networking. This requires tactical information. But network information is knowledge of society and culture; it is also moral knowledge. Therefore, although there will be cases where this will not hold (Hoselitz 1964; I. M. Lewis 1976, p. 232) we would expect to find many entrepreneurs to be experts in mainstream culture (Kilby 1971; on cross-cultural variability, Etzioni 1987).

Bigmen, certainly, were "cultural exemplars" (in Geertz's 1967, term for another example). We have seen that they were role models and political leaders. They were also culturally adept. They had to "be able to dance correctly, with verve, and have a wide knowledge of the various melodies, rhythms, and choreographies" (Burridge 1970, p. 75). Since they had to be able to sway public opinion, to persuade others to join in their ventures, they had also to be masterly orators and rhetoricians (Burridge 1970; Keesing 1978, 1985; Lindstrom 1984; Meggitt 1974; Rodman and Counts 1982; Strathern 1971; for non-Melanesian examples, see Benedict 1968; Geertz 1967).

Actors who are morally central, such as Bigmen, know how far they can push against the edges of moral orders. Burridge put it this way: "[Bigmen] solve best and most fruitfully the issues of self-will and moral responsibility... [T] hey are the men who can exploit to the utmost certain selected capacities without overstepping moral equality" (1970, p. 203). They could read public opinion, "withdrawing from situations [with] too many variables", while still attempting "to create opportunities and force issues" (Burridge 1970, pp. 77-78; non-Melanesian instances are in Gulliver 1971; Tiffany 1975; Turner 1957).

Entrepreneurs do seem sometimes to be at the margins. Those who can see more than one moral order, one sphere of exchange, are often the most widely travelled, and thus the most syncretic and cosmopolitan. This was true of many Bigmen, who, because they inspired envy, were exposed to the suspicions of sorcery that track the outsider. Their skills included the ability to take these moral risks, to breach certain norms, yet still be morally central (Belshaw 1955; Burridge 1970; 1975; Oliver 1949a; Pflanz-Cook and Cook 1982; Sahlins 1963; Strathern 1972; non-Melanesian references are Moench 1971; Papanek 1973; Salovesh 1978; Tiffany 1975).

\section{Moral Ambiguity}

If entrepreneurs are committed to, and experts in, communities they need for their resources, they clearly are not one-dimensional, not simply tactical creatures. Yet entrepreneurship may be morally problematic or ambiguous, if only because it can be licit or illicit (Hart 1975). A more basic reason is that it is enmeshed in the relativity of moral orders and social process.

Most of the time entrepreneurs are not apparently "entrepreneurial". They are engaged in embedding, in contexts of defensive or monopolistic niches. They are also engaged in re-embedding. Even those out on a normative limb often convert their spoils to traditional, or new, tokens of prestige; or, failing this, to institutionalize a new moral order (Gold 1975; Hart 1975; Papanek 1973; Tiffany 1975). That being said, there is no denying that at times they disembed.

Their flouting of normative orders can, in the extreme, destroy their social system (Levine 1985; Smith 1986). More typically (and less dramatically) they find it hard to resolve the conflict between "accumulation and social obligation" (Hart 1975, p. 2). Ethnic and kin obligations, though valued both in themselves and as resources, generate uncertainties and "social welfare' pressures" (Geertz 1967, p. 388; Hart 1975; Long 1979). These can constrain productive reinvestment and expansion. "Once they are ready to expand into [broader] markets... entrepreneurs discover institutional 
barriers that cannot be negotiated ... in [a] face-to-face manner... [For this reason] they may find it necessary to... disengage themselves from [their primary] social relationships" (Robben 1984, p. 125; and Burridge 1975, pp. 93-94; Hart 1975; Light 1972; Strathern 1972).

Expansion to new arenas, and disembedding more broadly, can often be phased in the course of a career (Robben 1984). Hart described such a phasing in a study of the Frafras, a disadvantaged ethnic group in Ghana. The career of the Frafra entrepreneur is a mirror image of that of the Melanesian Bigman. The Bigman's career began with generosity; only later did the terms of trade turn in his favor. By contrast, early in the Frafra career, "when [the aspirant] is struggling to break out of the subsistence nexus, he is likely to ... fiercely [resist] transfers from himself to the community" (Hart 1975, p. 12). Only in the "final stage" does the direction of surplus flows reverse. (This could be an example of disconfirming a proposition, forcing us to ask if "Bigman" is a broad enough term to encompass this exception, if the Frafra represents a different mode of entrepreneurship, or if we have misunderstood the Bigman. A means of resolution-case replication - is suggested below.)

A very different case is that of "altruistic entrepreneurs", such as immigrants to Israel, bent on national economic development. Such people face acutely the dilemmas of disengagement. Although they are committed to their informal interest groups, they envision a new moral order (Avruch 1982). In order to be true to their new moral vision they must disengage from "traditional" moral pressures (and refuse to indulge in traditional vices) (Avruch 1982; Belshaw 1955; Geertz 1967; Light 1972; Marris 1975; Strathern 1972; cf. Papanek 1973).

\section{How Are Resources Mobilized?}

Entrepreneurship requires heavy investments in both the moral and tactical dimensions. The knowledge needed is a tactical resource, but also a moral commitment. Further, the tactically-oriented actor must first internalize and interpret norms in order to be able to change them. Not only this, but at a less conscious level, he or she must accept being manipulated by accepting the norms implied by membership in an arena (Cohen 1974, pp. 42-43). Entrepreneurs are both embedded "in", and tilted "at" their cultures. Their acts create moral changes which affect the tactical patterns, and tactical changes which affect the normative system.

A pattern often found in anthropology is one of moral changes driving tactical changes driving moral changes (Belshaw 1955; Cohen 1974; Turner 1957; see also Weber 1958 , pp. 58, 65, 91). Whichever we see as the dominant influence, individual tactics or collective norms, we still see tactics leading to a host of social and cultural changes (Moench 1971; Pflanz-Cook and Cook 1982; Salovesh 1978; Tiffany 1975; Turner 1957).

\section{What Skills Are Needed?}

If entrepreneurship entails typical tactics, these in turn entail typical skills. Skills of planning or foresight, and of the astute use of timing, are needed for tactics like conversions between spheres, brokerage and bridging, and investments in social networks.

The need for skills in planning, at least in the sense of thinking intently about future acts, seem to go hand in hand with opportunism. Certainly, this was true of Bigmen. Their planning followed from their need to mobilize people and resources (Belshaw 1965, p. 38; Oliver 1949b, p. 17; Strathern 1972, p. 375). It followed from their need to make decisions in terms of other tactics, such as bridging (Moench 1971; Pflanz-Cook and Cook 1982; Schneider and Schneider 1976). For example, it took "managerial capacities to foresee... occasions [for status-winning generosity] and not miss them" 
(Burridge 1970, p. 79). Therefore, Bigmen spent their time thinking "about pigs and money" while working on their other income-generating activities (Oliver 1949b, p. 17).

Closely related to planning is astute use of timing. Timing in management is little understood, but, it appears, allusions to timing often cover topics related to entrepreneurship, such as entry into new markets, investments, takeovers, and strategic change. Yet even in works on entrepreneurship, timing is more often noted than analyzed. Works on Melanesian Bigmen show in detail how astuteness in timing is a necessary skill. The Bigmen cashed in on the differing periodicities of exchange systems. They sought to control the timing of the rivalrous feasts. More broadly, they competed over timing; playing for time, pushing debtors, and scheming to sequence their creditors (Burridge 1975; de Lepervanche 1968; Keesing 1978; Lindstrom 1984; Meggitt 1974; Strathern 1971).

\section{Morals: Research Implications}

Implications of this story could be pursued with many research methods. Two somewhat unusual approaches will be recommended. One is synchronic and comparative; the other, diachronic and intensive. In both strategies, limits to library tales are the impetus to return to the field (just as limits to single-site comparisons led to the search for library tales).

Differing cases can be compared due to acts of "translation" (Noblit and Hare 1988), but translations are prone to three sources of failure. First, subjects and predicates may be insufficiently commensurable, especially when they cut across cultural borders (Swartz 1982). Bigmanship, for example, was much more embedded than Western entrepreneurship (Burridge 1975; Douglas 1967; Sahlins 1972, p. 250; cf. Pospisil 1968). Second, translations exact a cost in scholarly energy. Critical readings of ethnographic work, such as Turner (1957), require an understanding of a wide range of matters, such as Turner's trajectory away from structural-functionalism, and problematic treatment of the "matrilineal puzzle". (This puzzle hinges on apparent contradictions between residency patterns and rules for succeeding to rights.) Such a cost of erudition could be seen as excessive. Third, tales that are needed for constant comparisons might not be available, or might not report needed data. Gaps are inevitable if the theory to be developed is finely grained, as is common in ethnography.

\section{Case Replication Research}

These failings have stunted the cumulation of ethnographic theory, as has the common response of heading straight back to the field, either the same field as before, or another with few prospects for comparison (Barrett 1984). A strategy with better prospects for cumulating knowledge is multiple-site, case replication research. This involves a conscious search for sites with important points of contrast or disconfirmation (Leonard-Barton 1990; Yin 1984, pp. 39-40). It also requires predetermined questions (Yin 1984, pp. 48-53, 64), such as whether, within corporations, contextual variables promote Bigman-like behaviors, or if these behaviors can be steered to corporate, noncareerist goals (cf. Burgelman 1983; Luthans 1988).

The tasks of formulating questions, and setting priorities for case replications, can be simplified by mapping out the range of research issues and literatures. Table 1 partially sketches both for Bigmanship research. Matrixes such as these are suited to case replications, since both are mosaics of multidimensional tales. Their designs are synchronically comparative. An alternative, diachronic and intensive design is also recommended. This design homes in on questions implied by certain cell contents. 


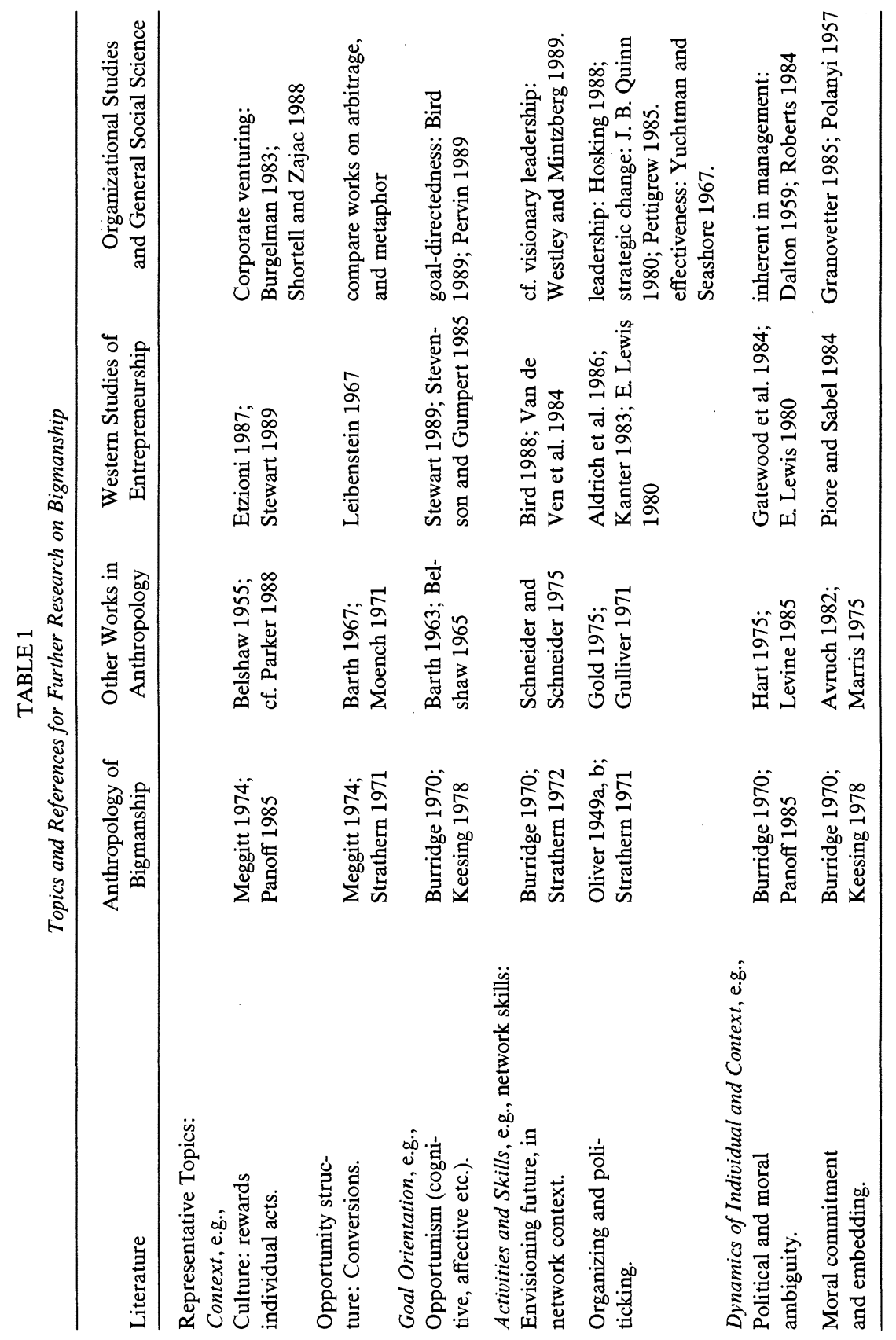




\section{Continuous Contextual Analysis}

Specific themes in the Bigman example, such as normative manipulation, opportunism, and personalized organizing, suggest an overarching theme: the complex relationships amongst constraints and individual agency (Giddens 1979; Reed 1988). The persistence of this theme in organizational research is demonstrated by recent writings on personal disposition (Davis-Blake and Pfeffer 1989; Pervin 1989), careers (Gunz 1989), institutional theory (DiMaggio 1988), and-several topics linked to entrepreneurship-corporate innovation (Feldman 1989; Shortell and Zajac 1988), strategic choice (Lawless and Finch 1989), top management (Covin and Slevin 1988; Daft, Sormunen and Parks 1988), and leadership (Hosking 1988; Thomas 1988; Yukl 1989).

This convergence, which returns us to our opening theme of political-economic leadership, extends to the interpretation that entrepreneurship is a form of leadership found in many contexts, and that both entrepreneurship and leadership employ generic skills, such as those for coping with ambiguity and contradiction, and for using social networks to build coalitions and mobilize (Hosking 1988; Low and MacMillan 1988; R. E. Quinn 1988; Yukl 1989). Popular exhortations to exert more of both of these "ships" (Bass 1985; Kouzes and Posner 1988; Peters 1987) imply this convergence in practitioners' concerns.

Convergence extends beyond themes to research agendas. According to recent review articles on leadership (Hosking 1988; Yukl 1989), researchers should try to do justice to political and interactive relationships, to "bottom-up" processes of organizing, and to the symbolic dimensions of these processes. They should try to overcome the fragmentation and noncumulative nature of previous work. These prescriptions can be applied without qualification to entrepreneurship, and likely to any issue of human agency and contextual constraint (Gunz 1989).

The problem of agency and constraint calls for the study of particular sets of actors, in specific situations, over (more or less) continuous time. It calls for continuous contextual analysis of the sort proposed by Van Velsen (1967), and represented by Gulliver (1971) and Turner (1957), and, in organizational research, by Kapferer (1969, 1972) and Pettigrew $(1973,1985)$. In these works, the detailed grounding in process data focuses on, but does not absolve, the need to interpret the actors' intentions. It does clarify linkages between explanation and data, but not between data and macro assumptions. It also does not resolve the tradeoff between breadth of comparison and depth of understanding. For these reasons, it would be best used in conjunction with other methods, such as case replications.

Case replications and continuous contextual analysis are difficult strategies to implement. Any adequate approach to the issues they address will be demanding on researchers' time, energies, and funds (Davis-Blake and Pfeffer 1989; Gunz 1989; Low and MacMillan 1988; Shortell and Zajac 1988; Thomas 1988). Any such approach, let alone combination, might thus be most feasible in teams. However, team research is fraught with personal and practical complications. Moreover, organizational fieldwork makes demands not only on researchers but also on subjects. This makes access problematic, yet with case replications particular sites must be accessed, so that opportunism in selecting sites, which otherwise could be serendipitous, is inappropriate. Processual and replication studies can fill in gaps on our library shelves, but the obstacles entailed are so intractable that library tales will continue to be helpful, and privately often imagined, if seldom publicly told.

\section{Acknowledgements}

Much of this material appeared in Part III of Stewart (1989), but wording and uses have been significantly changed, thanks to critiques from Arie Lewin, Dick Daft, and 
four anonymous reviewers. Thanks also to Howard Aldrich, Anne Huff, Tom Mulligan and Rein Peterson.

\section{References}

AldRich, H. AND C. Zimmer (1986), “Entrepreneurship through Social Networks, ” In D. L. Sexton \& R. W. Smilor (Eds.), The Art and Science of Entrepreneurship, 2-23, Cambridge, MA: Ballinger.

$\rightarrow$ Avruch, K. (1982), "New Markets and Good Deeds: On Altruism and Exemplary Entrepreneurship," Anthropological Quart., 55, 211-223.

BARretT, S. R. (1984), The Rebirth of Anthropological Theory, Toronto: University of Toronto Press.

BARTH, F. (1963), "Introduction," In F. Barth (Ed.), The Role of the Entrepreneur in Social Change in Northern Norway, 5-18, Oslo: Universitetsforlaget.

(1967), "Economic Spheres in Darfur," In R. Firth (Ed.), Themes in Economic Anthropology, 149-174, Tavistock, London.

Bass, B. M. (1985), Leadership and Performance Beyond Expectations, New York: Free Press.

$\rightarrow$ BECKER, H. S. (1958), "Problems of Inference and Proof in Participant Observation," Amer. Sociological Rev., 23, 652-660.

Belshaw, C. S. (1955), "The Cultural Milieu of the Entrepreneur," Explorations in Entrepreneurial History, $7,144-163$

(1965), Traditional Exchange and Modern Markets, Englewood Cliffs, NJ: Prentice-Hall.

$\rightarrow$ Benedict, B. (1968), "Family Firms and Economic Development," Southwestern J. Anthropology, 24, 1-19.

$\rightarrow$ BIRD, B. (1988), "Implementing Entrepreneurial Ideas: The Case for Intention," Acad. Management Rev., 13, 442-453.

BLOCH, M. (1971), “The Moral and Tactical Meaning of Kinship Terms," Man (N.S.), 6, 79-87.

Botr, E. (1971), Family and Social Network, 2nd ed., London: Tavistock:

Brockhaus, R. H. (1987), “Entrepreneurial Folklore," J. Small Business Management, (July), pp. 1-6.

Brown, P. (1987), "New Men and Big Men: Emerging Social Stratification in the Third World: A Case Study from the New Guinea Highlands," Ethnology, 26, 87-106.

$\rightarrow$ Burgelman, R. A. (1983), "A Process Model of Internal Corporate Venturing in the Diversified Major Firm," Admin. Sci. Quart., 28, 223-244.

Burridge, K. (1970), Mambu, New York: Harper \& Row.

(1975), "The Melanesian Manager," In J. H. M. Beattie \& R. G. Lienhardt (Eds.), Studies in Social Anthropology, Oxford, U.K.: Oxford University Press, 86-104.

CAmpbell, D. T. (1975), “'Degrees of Freedom' and the Case Study," Comparative Political Studies, 8, 178-193.

Cohen, A. (1969), Custom and Politics in Urban Africa, Berkeley: University of California Press. (1974), Two-Dimensional Man, Berkeley: University of California Press.

Covin, J. G. AND D. P. SLEvin (1988), "The Influence of Organization Structure on the Utility of an Entrepreneurial Top Management Style," J. Management Studies, 25, 217-234.

Crozier, M. (1964), The Bureaucratic Phenomenon, Chicago: University of Chicago Press.

DAFT, R. L., J. Sormunen AND D. PARKS (1988), "Chief Executive Scanning, Environmental Characteristics, and Company Performance: An Empirical Study,” Strategic Management J., 9, 123-139.

Dalton, M. (1959), Men Who Manage, New York: Wiley.

Davis-Blake, A. AND J. Pfeffer (1989), “Just a Mirage: The Search for Dispositional Effects in Organizational Research," Acad. Management Rev., 14, 385-400.

$\rightarrow$ DE Lepervanche, M. (1968), "Descent, Residence and Leadership in the New Guinea Highlands," Oceania, $38,163-189$.

DiMaggio, P. (1988), “Interest and Agency in Institutional Theory,” In L. G. Zucker (Ed.), Institutional Patterns and Organizations, 3-21, Cambridge, MA: Ballinger.

Douglas, M. (1967), "Primitive Rationing: A Study in Controlled Exchange," In R. Firth (Ed.), Themes in Economic Anthropology, 119-146, London: Tavistock. (1983), "Morality and Culture," Ethics, 93, 786-791.

Durkheim, E. (1974, first published in 1924), Sociology and Philosophy, (D. F. Pockock, trans.), New York: Free Press.

Etzioni, A. (1987), "Entrepreneurship, Adaptation and Legitimation," J. Economic Behavior and Organization, 8, 175-189.

Feldman, S. P. (1989), “The Broken Wheel: The Inseparability of Autonomy and Control in Innovation within Organizations," J. Management Studies, 26, 83-102.

Finney, B. R. (1973), “Big-Men, Half-Men, Trader-Chiefs in New Guinea and Polynesia,” In T. S. Epstein \& D. H. Penney (Eds.), Opportunity and Response, 114-130, London: C. Hurst. 
Gatewood, E., F. Hoy and C. Spindler (1984), "Functionalist vs. Conflict Theories: Entrepreneurship Disrupts the Power Structure in a Small Southern Community," In J. A. Hornaday et al. (Eds.), Frontiers of Entrepreneurship Research, 265-279, Wellesley, MA: Babson College.

GeErTz, C. (1967), "Social Change and Economic Modernization in Two Indonesian Towns: A Case in Point," In G. Dalton (Ed.), Tribal and Peasant Economies, 366-394, Garden City, NY: Natural History Press. $\rightarrow$ (1984), “Anti Anti-Relativism," Amer. Anthropologist, 86, 263-278.

GidDens, A. (1979), Central Problems in Social Theory, Berkeley: University of California Press.

GladE, W. P. (1967), “Approaches to a Theory of Entrepreneurial Formation," Explorations in Entrepreneurial History (Second Series), 4, 245-259.

Glaser, B. G. AND A. L. Strauss (1967). The Discovery of Grounded Theory, Chicago: Aldine.

Gold, G. L. (1975), St. Pascal, Toronto: Holt, Rinehart \& Winston.

Granovetrer, M. (1973), “The Strength of Weak Ties," Amer. J. Sociology, 78, 1360-1380.

(1985), "Economic Action and Social Structure: The Problem of Embeddedness," Amer. J. Sociology, 91, 481-510.

Greenfield, S. M. AND A. Strickon (1986), “Introduction,” In S. M. Greenfield \& A. Strickon (Eds.), Entrepreneurship and Social Change, Lanham, MD: University Press of America, 4-18.

Gulliver, P. H. (1971), Neighbours and Networks, Berkeley: University of California Press.

Gunz, H. (1989), “The Dual Meaning of Managerial Careers: Organizational and Individual Levels of Analysis," J. Management Studies, 26, 225-250.

HART, K. (1975), “Swindler or Public Benefactor? - The Entrepreneur in his Community,” In J. Goody (Ed.), Changing Social Structure in Ghana, London: International African Institute, 1-35.

Hoselitz, B. F. (1964), “A Sociological Approach to Economic Development," In D. E. Novack \& R. Lecachman (Eds.), Development and Society, New York: St. Martin's, 150-163.

Hosking, D. M. (1988), "Organizing, Leadership and Skillful Processes," J. Management Studies, 25, $147-166$.

KANTER, R. M. (1977), Men and Women of the Corporation, New York: Basic. (1983), The Change Masters, New York: Simon and Schuster.

KAPFERER, B. (1969), "Norms and the Manipulation of Relationships in a Work Context," In J. C. Mitchell (Ed.), Social Networks in Urban Situations, Manchester: Manchester University Press, 181-244. (1972), Strategy and Transaction in an African Factory, Manchester: Manchester University Press.

KeEsing, R. M. (1976), Cultural Anthropology, New York: Holt, Rinehart, and Winston. (1978), Elota's Story, St. Lucia, Australia: University of Queensland Press.

(1985), “Killers, Bigmen, and Priests on Malaita: Reflections on a Melanesian Troika System," Ethnologv, 24, 237-252.

KILBy, P. (1971), “Hunting the Heffalump,” In P. Kilby (Ed.), Entrepreneurship and Economic Development, 1-40, New York: Free Press.

Kouzes, J. M. AND B. Z. Posner (1988), The Leadership Challenge, San Francisco: Jossey-Bass.

LAwless, M. W. AND L. K. FINCH (1989), “Choice and Determinism: A Test of Hrebiniak and Joyce's Framework on Strategy-Environment Fit," Strategic Management J., 10, 351-365.

Leibenstein, H. (1968), “Entrepreneurship and Economic Development,” Amer. Economic Rev., 58, 72-83.

LeOnard-Barton, D. (1990), "Synergistic Design for Case Studies: Longitudinal Single-Site and Replicated Multiple-Site," Organization Sci., forthcoming.

Levine, H. B. (1985), “Entrepreneurship and Social Change: Implications from a New Zealand Case Study," Human Organization, 44, 293-300.

Lewis, E. (1980), Public Entrepreneurship, Bloomington: Indiana University Press.

Lewis, I. M. (1976), Social Anthropologv in Perspective, Harmondsworth, U.K.: Penguin.

Light, I. H. (1972), Ethnic Enterprise in America, Berkeley: University of California Press.

$\rightarrow$ Lindstrom, L. (1981), “'Big Man’: A Short Terminological History,” Amer. Anthropologist, 83, 900-905. $\rightarrow$ (1984), "Doctor, Lawyer, Wise Man, Priest: Big-Men and Knowledge in Melanesia," Man (N.S.), 19, 291-309.

LoNG, N. (1975), "Structural Dependency, Modes of Production and Economic Brokerage in Peru," In I. Oxaal, T. Barnett, \& D. Booth (Eds.), Beyond the Sociology of Development, 253-282, London: Routledge \& Kegan Paul.

(1979), "Multiple Enterprise in the Central Highlands of Peru,” In S. M. Greenfield, A. Strickon, \& R. T. Aubey (Eds.), Entrepreneurs in Cultural Context, 123-158, Albuquerque: University of New Mexico Press.

Low, M. B. AND I. C. MacMillan (1988), “Entrepreneurship: Past Research and Future Challenges,” $J$. Management, 14, 139-161.

$\rightarrow$ Luthans, F. (1988), "Successful vs. Effective Real Managers," Acad. Management Executive, 2, 127-132.

Marris, P. (1975), Loss and Change, Garden City, NY: Doubleday. 
Meggitr, M. J. (1974), “'Pigs Are Our Hearts!': The Te Exchange Cycle among the Mae Enga of New Guinea," In M. G. Meggitt, Studies in Enga History, The Oceania monographs No. 20, Australia: Sydney, 57-95.

MoEnCH, R. (1971), “Wealth, Expertise, and Political Entrepreneurship: Political Innovation in a Pacific Chinese Community," J. Asian and African Studies, 6, 37-48.

MoreY, N. C. AND F. LUTHANS (1987), "Anthropology: The Forgotten Behavioral Science in Management History," In F. Hoy (Ed.), Best Paper Proc., Acad. Management, 128-132.

Noblit, G. W. AND R. D. HARE (1988), Meta-Ethnography, Newbury Park, CA: Sage.

Oliver, D. L (1949a), "Economic and Social Uses of Domestic Pigs in Siuai, Southern Bougainville, Solomon Islands, Papers of the Peabody Museum, Harvard University, 29, 3.

(1949b), "Human Relations and Language in a Papuan-Speaking Tribe of Southern Bougainville, Solomon Islands," Papers of the Peabody Museum, Harvard University, 29, 2.

Panoff, M. (1985), “Une figure de l'abjection en Nouvelle-Bretagne: Le rubbish man," L'Homme, 25, 9, $57-71$.

PapaneK, H. (1973), “Pakistan's New Industrialists and Businessmen: Focus on the Memons," In M. Singer (Ed.), Entrepreneurship and Modernization of Occupational Cultures in South Asia, Duke University, Durham, NC: Duke University, 61-106.

Parker, B. (1988), "Moral Economy, Political Economy, and the Culture of Entrepreneurship in Highland Nepal," Ethnology, 27, 181-194.

$\rightarrow$ Pervin, L. A. (1989), "Persons, Situations, Interactions: The History of a Controversy and a Discussion of Theoretical Models," Acad. Management Rev., 14, 350-360.

Peters, T. (1987), Thriving on Chaos, New York: Knopf.

Pettigrew, A. M. (1973), The Politics of Organizational Decision Making, London: Tavistock. (1985), The Awakening Giant, Oxford, U.K: Basil Blackwell.

Pflanz-Cook, S. M. AND E. A. CooK (1982), “Mai of the Manga: Man of the Middle," In W. L. Rodman \& D. A. Counts (Eds.), Middlemen and Brokers in Oceania, Ann Arbor: University of Michigan Press, 233-266.

Piore, M. J. AND C. F. SABel (1984), The Second Industrial Divide, New York: Basic.

PolanYI, K. (1957), The Great Transformation, Boston: Beacon.

Pospisıl, L. (1968), “The Kapauku Individualistic Money Economy,” In E. E. LeClair \& H. K. Schneider (Eds.), Economic Anthropology, 381-394, New York: Holt, Rinehart, and Winston.

QuinN, J. B. (1980), Strategies for Change, Homewood, IL: Irwin.

QuinN, R. E. (1988), Beyond Rational Management, San Francisco: Jossey-Bass.

ReED, M. I. (1988), “The Problem of Human Agency in Organizational Analysis," Organization Studies, 9, 33-46.

ReYNoldS, P. AND B. Miller (1988), 1987 Minnesota New Firms Study, Minneapolis: Center for Regional and Urban Affairs.

Robben, A. C. G. M. (1984), "Entrepreneurs and Scale: Interactional and Institutional Constraints on the Growth of Small-Scale Enterprise in Brazil," Anthropological Quart., 57, 125-138.

Roberts, J. (1984), “The. Moral Character of Management Practice," J. Management Studies, 21, 287-302.

Rodman, W. L. AND D. Counts (1982), “Introduction," In W. L. Rodman \& D. A. Counts (Eds.), Middlemen and Brokers in Oceania, 1-33, Ann Arbor: University of Michigan Press.

Sahlins, M. D. (1963), "Poor Man, Rich Man, Big-Man, Chief: Political Types in Melanesia and Polynesia," Comparative Studies in Society and History, 5, 285-303. (1972), Stone Age Economics, Chicago: Aldine.

Salisbury, R. F. (1966), “Politics and Shell-Money Finance in New Britain,” In M. J. Swartz, V. W. Turner, \& A. Tuden (Eds.), Political Anthropology, 113-128, Chicago: Aldine.

Salovesh, M. (1978), "When Brokers Go Broke: Implications of Role Failure in Cultural Brokerage," In R. E. Holloman \& S. A. Arutiunov (Eds.), Perspectives on Ethnicity, 351-371, The Hague: Mouton.

SChNeider, J. AND P. SChNeIder (1976), Culture and Political Economy in Western Sicily, New York: Academic.

Shortell, S. M. AND E. J. ZaJAC (1988), "Internal Corporate Joint Ventures: Development Processes and Performance Outcomes," Strategic Management J., 9, 527-542.

SMITH, S. (1986), "Entrepreneurial Agriculture and the Involution of Agricultural Dynamics in the Americas," In S. M. Greenfield \& A. Strickon (Eds.), Entrepreneurship and Social Change, Lanham, MD: University Press of America, 96-123.

Stevenson, H. H. AND D. E. Gumpert (1985), “The Heart of Entrepreneurship," Harvard Business Rev., (March-April), 85-94.

StewarT, A. (1987), "Anthropology and the Practice of Entrepreneurship Research," In New Ventures: USASBE Proc., 106-112. (1989), Team Entrepreneurship, Newbury Park, CA: Sage. 
Strathern, A. J. (1971), The Rope of Moka, Cambridge, U.K: Cambridge University Press.

(1972), "The Entrepreneurial Model of Social Change: From Norway to New Guinea," Ethnology, 11, 368-379.

(1983), "The Kula in Comparative Perspective," In J. W. Leach \& E. Leach (Eds.), The Kula, 73-88, Cambridge, U.K.: Cambridge University Press.

Swartz, M. J. (1982), "Bridges, Metaphors and Theories: A Commentary," In W. L. Rodman \& D. A. Counts (Eds.), Middlemen and Brokers in Oceania, Ann Arbor: University of Michigan Press, 267-286.

Thomas, A. B. (1988), "Does Leadership Make a Difference to Organizational Performance?," Admin. Sci. Quart., 33, 388-400.

Tiffany, S. W. (1975), "Entrepreneurship and Political Participation in Western Samoa," Oceania, 46, $85-106$.

(1987), "Politics and Gender in Pacific Island Societies: A Feminist Critique of the Anthropology of Power," Women's Studies, 13, 333-355.

Turner, V. W. (1957), Schism and Continuity in an African Society, Manchester: Manchester University Press.

van Bakel, M. A., R. R. Hagesteijn and P. van de Velde (1986), “'Big Man’: From Private Politics to Political Anthropology,” In M. A. van Bakel, R. R. Hagesteijn, \& P. van de Velde (Eds.), Private Politics, Leiden: E. J. Brill, 211-215.

Van de Ven, A. H., R. Hudson and D. M. Schroeder (1984), “Designing New Business Startups: Entrepreneurial, Organizational, and Ecological Considerations," J. Management, 10, 87-107.

Van MaAnen, J. (1988), Tales of the Field, Chicago: University of Chicago Press.

VAn Velsen, J. (1967), “The Extended-Case Method and Situational Analysis,” In A. L. Epstein (Ed.), The Craft of Social Anthropology, 129-149, London: Tavistock.

WALDINGER, R. (1986), "Immigrant Enterprise: A Critique and Reformulation," Theory and Society, 15, 249-285.

Weber, M. (1958, originally published in German in 1904-1905), The Protestant Ethic and the Spirit of Capitalism, (T. Parsons, trans.), New York: Scribners.

Westley, F. AND H. Mintzberg (1989), “Visionary Leadership and Strategic Management," Strategic Management $J .$, 10, 17-32.

$\rightarrow$ Whyte, W. F. (1987), "From Human Relations to Organizational Behavior: Reflections on the Changing Scene," Industrial and Labor Relations Rev., 40, 487-500.

YIN, R. K. (1984), Case Study Research, Beverly Hills, CA: Sage.

$\rightarrow$ Yuchtman, E. And S. E. Seashore (1967), “A System Resource Approach to Organizational Effectiveness," Amer. Sociological Rev., 32, 891-903.

YUKL, G. (1989), "Managerial Leadership: A Review of Theory and Research,” J. Management, 15, 251-289. 